Cornell University Law School Scholarship@Cornell Law: A Digital Repository

\title{
Plaintiphobia in State Courts Redux? An Empirical Study of State Court Trials on Appeal
}

Theodore Eisenberg

Cornell Law School (deceased)

Michael Heise

Cornell Law School, michael.heise@cornell.edu

Follow this and additional works at: https://scholarship.law.cornell.edu/facpub

Part of the Courts Commons

\section{Recommended Citation}

Eisenberg, Theodore and Heise, Michael, "Plaintiphobia in State Courts Redux? An Empirical Study of State Court Trials on Appeal," 12 Journal of Empirical Legal Studies 100-127 (2015)

This Article is brought to you for free and open access by the Faculty Scholarship at Scholarship@Cornell Law: A Digital Repository. It has been accepted for inclusion in Cornell Law Faculty Publications by an authorized administrator of Scholarship@Cornell Law: A Digital Repository. For more information, please contact jmp8@cornell.edu. 


\title{
Plaintiphobia in State Courts Redux? An Empirical Study of State Court Trials on Appeal
}

\author{
Theodore Eisenberg and Michael Heise*
}

\begin{abstract}
Prior federal and state civil appeals studies show that appeals courts overturn jury verdicts more than bench decisions and that defendants fare better than plaintiffs on appeal. Attitudinal and selection effect hypotheses may help explain an appellate court tilt that favors defendants. This study builds on and extends our prior work on state civil appeals and examines a comprehensive state court civil appeals data set to test leading theories on appellate outcomes as well as to explore the relation between plaintiff success at trial and on appeal. Using data from 40 different states and 141 counties on 8,872 completed civil trials and 646 concluded appeals, we find that appellate reversal rates for jury trials and defendant appeals exceed reversal rates for bench trials and plaintiff appeals. The reversal rate for plaintiff appeals is 21 percent, compared with 40.9 percent for defendant appeals. The reversal rate for jury trials is 33.1 percent, compared with 25 percent for bench trials. Both the attitudinal and selection effect hypotheses find some level of support in our descriptive analyses and results from more formal models. Finally, we find little correlation between how plaintiffs fare at trial and how they fare on appeal.
\end{abstract}

\section{INTRODUCTION}

Appeals perform multiple and critical functions in our legal system, including error correction and facilitating the uniform application of legal rules. ${ }^{1}$ In discharging their functions and seeking to reconcile the competing desires for finality and accuracy, appealed cases also form the foundation of what most observers know about the legal system. More specifically, appellate decisions dominate casebooks, establish doctrine that binds trial courts, and are more accessible to researchers than are the mass of unappealed trial court decisions.

Despite their importance, appellate decisions can too easily distort perceptions of the legal system. After all, it is the unusual legal dispute that persists through a trial and

\footnotetext{
*Theodore Eisenberg (1947-2014); address correspondence to Michael Heise, Professor, Cornell Law School, Myron Taylor Hall, Ithaca, NY 14853.

Ted Eisenberg suddenly and tragically passed away recently, and prior to this article's publication. Ted was a brilliant colleague and gracious mentor. My many collaborations with Ted are-and will endure as-among my most cherished as a law professor. Many, including me, miss Ted deeply.
}

'Cassandra Burke Robertson, The Right to Appeal, 91 N.C. L. Rev. 1219 (2013). 
generates a trial court decision. As Siegelman and Donohue demonstrated in the employment discrimination context, tried cases that generate written opinions constitute only the tip of a large underlying iceberg of adjudicated discrimination cases. ${ }^{2}$ Appellate litigation culminating in an appellate court decision is rarer still. Even though appellate court decisions do not accurately reflect the much larger body of legal activity that takes place prior to an appeal, what happens to cases on appeal warrants consideration. More specifically, appellate outcomes, particularly in relation to trial court outcomes, deserve careful study. To this end, this article explores the relation between trial and appellate court outcomes and seeks to contribute to a growing empirical literature.

We know comparatively little about the relation between trial and appellate court outcomes. Until relatively recently, a paucity of helpful data frustrated scholars interested in such issues. Existing empirical scholarship on the rates of appeal and factors influencing decisions to appeal favors federal court data; ${ }^{3}$ far less is known about these issues in the state court context. ${ }^{4}$ The scholarly bias favoring federal courts is odd, particularly, as Galanter notes, since the vast bulk of civil litigation-including appellate litigation-occurs in state courts. $^{5}$

A paucity of data has not dampened the formation of both opinions and conventional wisdom concerning appellate outcomes and their relation to trial court outcomes. Indeed, if anything, a data vacuum enhances the influence of opinions, perceptions, anecdotes, and casual impressions. For example, standard advice to appellate lawyers typically emphasizes the sanctity of jury verdicts and warns that "appellate challenges to jury findings rarely succeed." ${ }^{6}$ Not surprisingly, such advice informs concrete decisions at the beginning of the litigation process when a lawyer's decision about whether to select a jury trial pivots partly on popular perceptions about the comparative resilience of jury outcomes to appellate review. ${ }^{7}$

\footnotetext{
${ }^{2}$ Peter Siegelman \& John J. Donohue III, Studying the Iceberg from its Tip: A Comparison of Published and Unpublished Employment Discrimination Cases, 24 L. \& Soc'y Rev. 1133 (1990).
}

${ }^{3}$ Kevin M. Clermont \& Theodore Eisenberg, Appeal from Jury or Judge Trial: Defendants' Advantage, 3 Am. L. \& Econ. Rev. 125 (2001); Theodore Eisenberg, Appeal Rates and Outcomes in Tried and Nontried Cases: Further Exploration of Anti-Plaintiff Appellate Outcomes, 1 J. Empirical Legal Stud. 659 (2004).

\footnotetext{
'Theodore Eisenberg \& Michael Heise, Plaintiphobia in State Courts? An Empirical Study of State Court Trials on Appeal, 38 J. Legal Stud. 121 (2009); Donald J. Farole \& Thomas H. Cohen, Litigating Civil Cases in State Intermediate Appellate Courts: Analyzing Decisions to Appeal Civil Trial Verdicts or Judgments and the Impact of Appellate Litigation on Trial Court Outcomes (2013) (unpublished manuscript, on file with author).
}

${ }^{5}$ Marc Galanter, The Vanishing Trial: An Examination of Trials and Related Matters in Federal and State Courts, $1 \mathrm{~J}$. Empirical Legal Stud. 459 (2004).

${ }^{6}$ George A. Somerville, Standards of Appellate Review, in Appellate Practice Manual 25 (Pricilla A. Schwab ed., American Bar Association 1992).

${ }^{7}$ Roger S. Haydock \& John Sonsteng, Trial: Theories, Tactics, Techniques 81 (West Group 1991). 
Holding conventional wisdom and perceptions up to empirical light, however, frequently uncovers surprises. ${ }^{8}$ Contrary to received wisdom, for example, studies find that jury verdicts are more prone to reversal than bench verdicts. ${ }^{9}$ As well, defendants' success with appeals systematically and substantially exceeded plaintiffs' success and both success rates, on average, fell below 50 percent ${ }^{10}$ despite informed speculation and theory suggesting that appellate success rates should be near 50 percent. " Moreover, Clermont, Eisenberg, and Schwab note that these general findings presented with even greater force within specific case types. ${ }^{12}$

This article exploits a unique data set ${ }^{13}$ that follows a comprehensive cohort of tried state court cases through their conclusion at the appellate level. The 2005 appeals data set follows up the initial 2001 iteration and facilitates comparisons over time. The 2005 appeals data set complements the 2001 data set by adding a subsample of state civil litigation from nonurban counties. Using these recently released data, we extend our earlier work on state court appeal rates and outcomes ${ }^{14}$ not subject to traditional concerns about opinion availability and lack of information about all trial outcomes. In particular, by following a cohort of trials to conclusion, these state court data avoid the problems of ex post efforts to match trial outcomes and appeals ${ }^{15}$ and permit unprecedented analyses of state court appeals.

Systematic research on state civil appeals of trials can accomplish several goals. Such research helps test litigation theories generated by law and economics and other scholars. Testing theories using state appeals is warranted in its own right because appeals provide the bulk of our knowledge of the legal system and "the great preponderance of trials, both civil and criminal, take place in the state courts." ${ }^{16}$ Comparisons with federal appellate research provide an opportunity to assess consistency of state and federal court patterns as well as the robustness of findings from prior work on federal appeals. This study of state appeals benefits from a BJS-NCSC data sct designed expressly for systematic study of the

${ }^{8}$ See, e.g., Clermont \& Eisenberg, supra note 3; Eisenberg \& Heise, supra note 4.

${ }^{9}$ Clermont \& Eisenberg, supra note 3; Eisenberg \& Heise, supra note 4.

${ }^{10}$ Kevin M. Clermont \& Theodore Eisenberg, Plaintiphobia in the Appellate Courts: Civil Rights Really Do Differ from Negotiable Instruments, 2002 U. Ill. L. Rev. 947 (2002); Eisenberg \& Heise, supra note 4.

"George L. Priest \& Benjamin Klein, The Selection of Disputes for Litigation, 13 J. Legal Stud. 1 (1984).

${ }^{12}$ Kevin M. Clermont, Theodore Eisenberg \& Stewart J. Schwab, How Employment-Discrimination Plaintiffs Fare in Federal Courts of Appeals, 7 Em. Rts. \& Emp. Pol'y J. 547 (2003).

${ }^{13}$ U.S. Dep't of Justice, Civil Justice Survey of Trials on Appeal, 2005 (ICPSR 32501) (2012), available at <http:// doi.org/10.3886/ICPSR32501.v1>.

${ }^{14}$ Eisenberg \& Heise, supra note 4.

${ }^{15}$ See, e.g., Eisenberg, supra note 3; Clermont \& Eisenberg, supra note 10.

${ }^{16}$ Galanter, supra note 5 , at 506 . 
appeals process. ${ }^{17}$ Although helpful descriptive work using the state appeals data set sketches the broad contours of the state appeals terrain, ${ }^{18}$ our study also empirically tests competing hypotheses on appellate outcomes.

Our full sample of both trial and appellate court outcomes also allows comparing success rates across case categories in two ways. First, one can observe whether parties are more successful on appeal in particular case categories. Indeed, controlling for case category is an important part of analyzing appellate outcomes such as comparative reversal rates between judge and jury trials and between plaintiff appeals and defendant appeals.

Second, the data provide a rare opportunity to study the relation between parties' success at two procedural stages-trial and appeal. Prior research suggests that case categories that fare well or poorly compared to other case categories at one stage of federal district court litigation also fare relatively well or poorly at other stages of such litigation. ${ }^{19}$ For example, employment discrimination cases fare worse than most other civil cases in terms of rates of settlement, pretrial dismissals, and trial outcomes. ${ }^{20}$ Little research exists about whether such relations persist between trial court outcomes and appellate outcomes. Study of these relations is important because data about trial court outcomes are difficult and expensive to collect. Researchers often have only sets of appellate cases or published opinions readily available. If strong correlations exist between success at trial courts and success on appeal, then reasonable inferences may be drawn from samples limited to appellate cases. The relations also have important implications for the study of selection effects. If case categories that fare poorly at one stage also fare poorly at another stage, then some characteristic of the category, such as plaintiff behavior, defendant behavior, or judicial behavior, transcends selection effects.

Key descriptive findings in this study include that, similar to civil trials in state courts, appeals are comparatively rare events. In our data set of 8,872 completed state court trials, only 11.6 percent stimulated an appeal. Of the 1,027 trials that continued to the appeal process, 646 , or just over 60 percent, culminated in a final appellate court decision. For all practical purposes, trial court decisions effectively terminate the bulk of legal disputes they address.

We also find that the state appellate court outcomes are asymmetric in two noteworthy ways. First, although state appellate courts affirmed trial court decisions in more than two-thirds of all cases, appellate courts were more likely to upset jury rather than

\footnotetext{
${ }^{17}$ Federal appeals studies using Administrative Office of the United States Courts (AO) data, while important, must work with data sets not expressly designed for appeals studies.

${ }^{18}$ U.S. Dep't of Justice, Appeals from General Civil Trials in 46 Large Counties, 2001-2005 (U.S. Gov't Printing Office 2005).

${ }^{19}$ Theodore Eisenberg, The Relationship Between Plaintiff Success Rates Before Trial and at Trial, 154 J. Royal Statistical Soc'y, Series A 111 (1991).

${ }^{20}$ Kevin M. Clermont \& Stewart J. Schwab, Employment Discrimination Plaintiffs in Federal Court: From Bad to Worse? 3 Harv. L. \& Pol'y Rev. 106 (2009); Laura Beth Nielsen, Robert L. Nelson \& Ryon Lancaster, Individual Justice or Collective Legal Mobilization? Employment Discrimination Litigation in the Post Givil Rights United States, $7 \mathrm{~J}$. Empirical Legal Sud. 175 (2010).
} 
bench trials. Second, defendants were far more successful than plaintiffs in securing a reversal of a trial court outcome. A plaintiff victory in front of a jury was the most likely scenario to generate an appellate court reversal. Our results also suggest that appellate court attitudes and assumptions about trial courts likely shape the observed pattern of appeal outcomes even after accounting for the selection of cases to appeal. Much of what we find in the 2005 data comports with our earlier findings from our 2001 data; other findings surprise and provide additional texture to our understanding of state civil appellate outcomes.

We further find that case category can matter. In our most complete model, professional malpractice cases (as distinct from medical malpractice cases) are most likely to be appealed and fraud cases are most likely to be reversed. In results that go beyond our 2001 findings, we show little correlation between how plaintiffs fare at trial and how they fare on appeal.

Section II outlines the two major competing theories seeking to explain the asymmetrical appellate outcomes. Section III describes our data, methodology, and research design with particular attention to how additions to the 2005 appeals data set may influence comparisons to prior work using the 2001 appeals data set. Section IV presents descriptive results that illustrate the contours of the stream of state civil cases from trial court verdict through the initial appeals process. Section V reports our regression results, which both support and refine the core descriptive results presented in Section IV. Section VI concludes.

\section{Competing Theories on Plaintiphobia}

The theoretical literature on the relation between trial and appellate outcomes is limited. Influential work by Priest and Klein establishes a theoretical frame suggesting that plaintiff success both at trial and on appeal should be approximately 50 percent. $^{21}$ An equally limited-though growing-empirical literature on the relation between trial and appellate outcomes, including our own prior work, brings data to Priest and Klein's hypotheses and sets out to explore reasons for departures from Priest and Klein's 50 percent hypothesis. ${ }^{22}$

Two recent empirical papers that explore appeals warrant note as they help locate this article's contribution to the growing empirical literature. First, preliminary work by Farole and Cohen uses the newly released 2005 appeals data set, but explores different hypotheses and employs a slightly different research design. ${ }^{23}$ Technical differences in data and methods notwithstanding, our general findings comport with Farole and Cohen's

\footnotetext{
${ }^{21}$ Priest \& Klein, supra note 11.

${ }^{22}$ One exception to the general finding of asymmetric reversal rates favoring defendants involves an empirical study of the Israel Supreme Court. Theodore Eisenberg, Talia Fisher \& Issi Rosen-Zvi, Israel's Supreme Court Appellate Jurisdiction: An Empirical Study, 96 Cornell L. Rev. 693 (2011).
}

${ }^{23}$ Farole \& Cohen, supra note 4. 
preliminary findings. Second, a recently published paper by Eisenberg and Farber uses a different appeals data set and context (federal appeals), but explores reasons for asymmetric appeals outcomes. ${ }^{24}$ Eisenberg and Farber do not attribute plaintiffs' lack of appellate success to a trial court tilt favoring plaintiffs or to plaintiffs' greater appetite for filing appeals; instead, they point to plaintiffs' willingness to press comparatively less successful legal claims into litigation. Notably, however, Eisenberg and Farber define legal claims as "less successful" if a trial court decision was upset on appeal. ${ }^{25}$

This article engages with questions arising from asymmetrical appellate outcomes in state civil courts that favor defendants. Theory and prior empirical scholarship supply two hypotheses that compete to explain a key finding of an appellate court outcome tilt favoring defendants-the attitudinal and selection effect hypotheses. Farole and Cohen's paper focuses on slightly different research hypotheses, though they use the 2005 state civil appeals data set. ${ }^{26}$ While Eisenberg and Farber focus on asymmetrical outcomes, they use appeals data from federal courts. ${ }^{27}$ By using the 2005 state civil appeals data set, our article sets out to test the two competing hypotheses, extend and build on our prior work, and bridge the scholarly space created by the Farole and Cohen and Eisenberg and Farber papers.

\section{A. Differential Attitude Hypothesis}

The differential attitude hypothesis (hereinafter, the "attitudinal hypothesis") ${ }^{28}$ emphasizes the possibility that either trial courts exhibit a pro-plaintiff bias or appeals courts perceive (or mis-perceive) trial courts as being pro-plaintiff. Notable anecdotal evidence of different trial court and appellate perspectives, and of appellate suspicion about trial court behavior, comes from the Supreme Court's decision in Cooper Industries, Inc. v. Leatherman Tool Group, Inc. ${ }^{29}$ That case requires appellate courts to "apply a de novo standard of review when passing on district courts' determinations of the constitutionality of punitive damages awards." 30 Such nondeferential review of trial court decisions about an issue often involving the size of awards would be unnecessary absent an assumption that appellate and trial courts have differing attitudes. Decisional bias is implied by differences in trial and appeals court

\footnotetext{
${ }^{24}$ Theodore Eisenberg \& Henry S. Farber, Why Do Plaintiffs Lose Appeals? Biased Trial Courts, Litigious Losers, or Low Trial Win Rates? 15 Am. L. \& Econ. Rev. 73 (2013).

${ }^{25} \mathrm{Id}$. at 80.

${ }^{26}$ Farole \& Cohen, supra note 4.

${ }^{27}$ Eisenberg \& Farber, supra note 24.

${ }^{28}$ We use the term "attitudinal" with some caution in this context. Although the term has a specific meaning in the judicial decision-making literature (see generally Jeffrey A. Segal \& Harold J. Spaeth, The Supreme Court and the Attitudinal Model Revisited (Cambridge University Press 2002)), we use the term here to refer not to judicial background or belief variables, but to group-level attitudinal differences between appellate and trial court judges.
}

${ }^{29} 532$ U.S. 424 (2001).

${ }^{30}$ Id. at 436 . 
outcomes as well as the starkly asymmetrical distribution of appeals outcomes between plaintiffs and defendants. This hypothesis assumes that bias can influence appellate (and trial) outcomes, and benefits from empirical support. ${ }^{31}$

What might plausibly account for an appellate court bias against plaintiffs and what are we to make of it? First, trial courts may favor plaintiffs. One source of potential bias flows from natural empathy with a victim, an impulse to make victims whole, and a willingness to redistribute wealth from a comparatively deeper economic pocket to an aggrieved plaintiff. Unlike appellate courts, trial courts do not deal with a "cold" record and are less concerned with opinion writing and the future effect of their decisions. ${ }^{32}$

Second, even if trial court bias does not exist, appellate courts may assume that such a bias exists and act to adjust accordingly. Indeed, persistent public characterizations of a "liability crisis" may help frame appellate courts' perceptions of trial court decisions. Prior research emphasizes that persistent misperceptions of a liability crisis can pervade not only the populace, but the legal profession as well. ${ }^{33}$ Many envision an "out of control" civil justice system. ${ }^{34}$ In such a context, why should we assume that appellate court judges are immune? ${ }^{35}$ Regardless of whether appellate courts accurately or inaccurately assume that trial courts favor plaintiffs, appellate courts may nonetheless tilt in defendants' favor to offset a perceived trial court bias favoring plaintiffs. Thus, for either reason (or both), the attitudinal hypothesis suggests that one might expect trial courts to favor plaintiffs relative to appellate courts.

\section{B. Selection Effect Hypothesis}

A second plausible hypothesis is case-selection based and posits that plaintiffs and defendants systematically appeal cases of different quality and type and that the resulting different case streams explain asymmetric appellate reversal rates. Three factors plausibly interact and contribute to systematically different case streams: differential stakes, litigation and settlement incentives, and differences between defendants and plaintiffs. Although generating specific quantitative predictions based on selection effect considerations can be difficult, ${ }^{36}$ ignoring selection effect considerations would be naive. ${ }^{37}$

\footnotetext{
${ }^{31}$ See, e.g., Lynn M. LoPucki \& Walter O. Weyrauch, A Theory of Legal Strategy, 49 Duke L.J. 1405 (2000).

32Michael Tigar, Federal Appeals: Jurisdiction and Practice (Shepard's/McGraw-Hill 2d ed. 1993).

${ }^{83}$ Kevin M. Clermont \& Theodore Eisenberg, Trial by Jury or Judge: Transcending Empiricism, 77 Cornell L. Rev. 1124 (1992); Marc Galanter, A World Without Trials? 2006 J. Disp. Resol. 7 (2006).

${ }^{34}$ Galanter, supra note 33 , at 21 .
}

${ }^{35}$ James L. Robertson, Reality on Appeal, in The Litigation Manual: Special Problems and Appeals 142-49 (John G. Koeltl \& John Kiernan eds., American Bar Association 3d. ed. 1999).

${ }^{36}$ Steven Shavell, Any Frequency of Plaintiff Victory at Trial is Possible, 25 J. Legal Stud. 493 (1996).

${ }^{37}$ Kevin M. Clermont \& Theodore Eisenberg, Litigation Realities, 88 Cornell L. Rev. 119 (2002). 
Plaintiffs and defendants might possess different stakes in a lawsuit and, if so, selection theory implies that the side with comparatively more at stake should be willing to settle its weakest cases and, in so doing, increase its win rate for those cases fully adjudicated. ${ }^{38}$ The overall plaintiff win rate for civil trials in state courts was approximately 56.4 percent, ${ }^{39}$ and it remains possible that the slightly higher plaintiff trial win rate might evidence plaintiffs' higher stakes. ${ }^{40}$ Just as plaintiffs' higher stakes in cases should boost their trial win rates, the selection hypothesis also predicts that the side with presumably lower stakes (defendants), having lost more cases at trial, would have more opportunities to appeal. More important, however, is that plaintiffs, whose hypothesized higher case stakes should make them more selective about what cases to push at trial, should be equally careful about only pushing strong cases on appeal. If so, appeal reversal rates for plaintiffs would approximate the defendants' reversal rate, if not exceed it.

Differences in plaintiff and defendant litigation and settlement incentives might also help explain differences in plaintiff and defendant reversal rates on appeal. Eisenberg and Farber suggest that plaintiffs tend to systematically select to press into litigation cases that appellate court outcomes imply are less meritorious cases, implying that plaintiffs and defendants value cases differently. ${ }^{41}$ Plaintiffs with the lowest litigation costs have an incentive to litigate comparatively less meritorious cases. ${ }^{42}$ Defendants, in contrast, do not "select into" litigation; rather, plaintiffs select defendants and one cannot unreasonably assume plain tiffs select defendants independent of a defendant's litigation costs. The interaction of such plaintiffs and defendants thusly motivated can contribute to asymmetric appellate outcomes.

Plaintiff and defendant differences involving decisions to pursue litigation parallel plaintiff and defendant differences in terms of settlement strategy. That is, unevenness in evaluating the merits of a potential lawsuit may persist in terms of evaluating potential settlement offers. Even assuming that plaintiffs and defendants have different incentives when it comes to settlements, however, to be coherent, the settlement explanation must also assume that defendants that lost at trial would settle their weakest appeals and that those defendants victorious at trial would set out to stonewall appealing plaintiffs on appeal. Such strategic defendant conduct, however, strikes us as implausible so long as one assumes that some defendants that lost at trial with objectively weak cases are nonetheless still motivated to file an appeal in the hope of a long-shot victory and with the certainty of prolonging the appellate process if only to delay the legal day of

${ }^{38}$ Clermont \& Eisenberg, supra note 3.

${ }^{39}$ U.S. Dep't of Justice, Civil Bench and Jury Trials in State Courts, 2005 (U.S. Gov't Printing Office 2008 ).

${ }^{40}$ Clermont \& Eisenberg, supra note 3.

${ }^{41}$ Eisenberg \& Farber, supra note 24.

${ }^{42}$ Eisenberg \& Farber, supra note 24 , at 80 . 
reckoning. ${ }^{43}$ After all, defendants who pressed objectively weak cases to trial may not suddenly change attitudes and tactics posttrial.

Alternative selection effect theorists advance other factors that distinguish plaintiffs and defendants that could account for asymmetrical appellate reversal rates. For example, while losing defendants might emphasize cost-benefit analysis when it comes to settlement decisions, Posner notes that losing plaintiffs, by contrast, might emphasize a desire to "be heard fully" on appeal, perhaps regardless of their objective chances on appeal. ${ }^{44}$ If so, one would expect an appellate rate to favor defendants as they would be pursuing objectively stronger appeals, as Eisenberg and Farber find. ${ }^{45}$

\section{Data, Methodology, and Research Design}

Two distinct, though related, data sets supply the data necessary for this study. First, the "Civil Justice Survey of State Courts," a project of the National Center for State Courts (NCSC) and the U.S. Department of Justice's Bureau of Justice Statistics (BJS), gathered data directly from state court clerks' offices on tort, contract, and property cases disposed of by trial during calendar year $2005 .{ }^{46}$ The 2005 Civil Justice Survey data set includes 46 of the 75 most populous counties, selected to maintain backward compatibility with earlier Civil Justice Surveys data sets. The 2005 survey expanded coverage by adding 110 counties to represent the 3,066 smaller counties not included in the country's 75 largest counties. ${ }^{47}$ The 2005 data include 8,872 concluded trials from 141 different counties and 40 different states.

The second data set used in this study complements the first. NCSC and BJS implemented a follow-up study that supplemented the 2005 civil trials data set by tracking the 1,290 cases where the trial verdict or judgment, concluded by trial during calendar 2005 , engaged in an initial appeal to an intermediate appellate court or a state's court of last resort by December 2009 (Civil Justice Survey of Trials on Appeal 2005).$^{48}$ Of this universe

\footnotetext{
${ }^{43}$ Harlon L. Dalton, Taking the Right to Appeal (More or Less) Seriously, 95 Yale L.J. 62 (1985); David A. Hyman, Bernard S. Black, Kathryn Zeiler, Charles Silver \& William M. Sage, Do Defendants Pay What Juries Award? PostVerdict Haircuts in Texas Medical Malpractice Cases, 1988-2003, 4 J. Empirical Legal Stud. 3 (2007).

${ }^{44}$ Richard A. Posner, The Federal Courts: Crisis and Reform (Harvard University Press 1985).

${ }^{4.5}$ Eisenberg \& Farber, supra note 24.

${ }^{46}$ U.S. Dep't of Justice, supra note 13.

${ }^{47}$ For a summary of the trial data set and methodology, see U.S. Dep't of Justice, supra note 39 (description); U.S. Dep't of Justice, Civil Justice Survey of State Courts, 2005, Codebook (ICPSR 23862) (2011), available at <http:// doi.org/10.3886/ICPSR23862.v2> (methodological summary). See also Theodore Eisenberg \& Michael Heise, JudgeJury Difference in Punitive Damages Awards: Who Listens to the Supreme Court? $8 \mathrm{~J}$. Empirical Legal Stud. 325 , 329-30 (2011) (describing the 1992, 1996, 2001, and 2005 data sets).
}

${ }^{48}$ For a summary of the appeals data set and methodology, see U.S. Dep't of Justice, supra note 13, Codebook (methodological summary). This study focuses on primary appeals and excludes from analyses the 226 secondary (or 
of 1,290 initial appeals, 20 (1.6 percent) were excluded from many of our analyses because the appeals lacked critical information about which party prevailed at trial. In all, raw appeals data come from 99 different counties and 35 different states.

Because this study dwells on traditionally adverse appeals from trial court decisions, cases where it was not clear that the nature of the appeal was adverse were excluded from the sample. For example, if the trial court ruled for the plaintiff, most would expect that the defendant would be the appellant in any appeal. Conversely, where the trial court ruled for the defendant, one would expect the plaintiff to be the appellant. For the most part (in 79.9 percent of the appeals), these expectations were met. Excluding a relatively small subgroup of nonadverse appeals generates a universe of 1,027 usable appeals and permits a more accurate picture of appeals by plaintiffs and defendants from trial court judgments entered against them. The appeal rate, drawn from the pool of adverse appeals, is the percentage of trial court judgments for one party or the other that the losing party puts onto the appellate docket. ${ }^{49}$

Merging the two NCSC and BJS data sets generates a unique source of data: a longitudinal view of the universe of state appellate activity drawn from the most representative sample of state trial activity in the United States. These data facilitate the systematic study of appeals of trials. With direct access to the state court clerk's offices, as well as approximately 100 trained coders recording data, the data set avoids traditional limitations incident to relying on litigants or third parties to report. Self-reports, common in many commercial verdict reporters, typically overstate plaintiff win rates and damage award levels. ${ }^{50}$

Despite the state civil appeals data set's unique strengths, it is not without limitations. First, insofar as we focus on appeals, our study is therefore conditioned on a trial court disposition. Second, our data only include tried cases and therefore do not include cases appealed after dispositive pretrial motions. Third, the focus on state courts dampens any impulse to generate implications about civil appellate activity in federal courts.

Selection effects also appear to influence our data set in various ways. As Figure 1 and Table 1 illustrate, the stream of cases encounters an array of filters as it proceeds from the civil dispute stage through the trial and appeal processes. ${ }^{51}$ Notably, as only a small fraction of civil actions filed reach trial, the pool of tried cases may systematically differ from the larger pool of civil disputes from which they emerged. Moreover, the appeal process itself

tertiary) appeals. For a similar analytical approach, see Donald J. Farole \& Thomas H. Cohen, Bureau of Justice Statistics Special Report: Appeals of Civil Trials Concluded in 2005 (U.S. Gov't Printing Office 2011). Of the 1,027 cases that involved an adverse appeal, five (or 0.4 percent) remained pending at the end of the December 2009 study period and were thus excluded from analyses.

${ }^{49}$ Clermont \& Eisenberg, supra note 3.

${ }^{50}$ Theodore Eisenberg, John Goerdt, Brian Ostrom, David Rottman \& Martin T. Wells, The Predictability of Punitive Damages, 26 J. Legal Stud. 623 (1997); Deborah J. Merritt \& Kathryn A. Barry, Is the Tort System in Crisis? New Empirical Evidence, 60 Ohio St. L.J. 315 (1999).

${ }^{51}$ While our results in Figure 1 and Table 1 overwhelmingly comport with Farole and Cohen's (supra note 48, at fig.1, tbl.1), they are not identical due to slightly different case flitering protocols. 
Figure 1: Flow of state trials disposed in 123 counties that were appealed to an intermediate or highest appellate state court, 2005-2009.

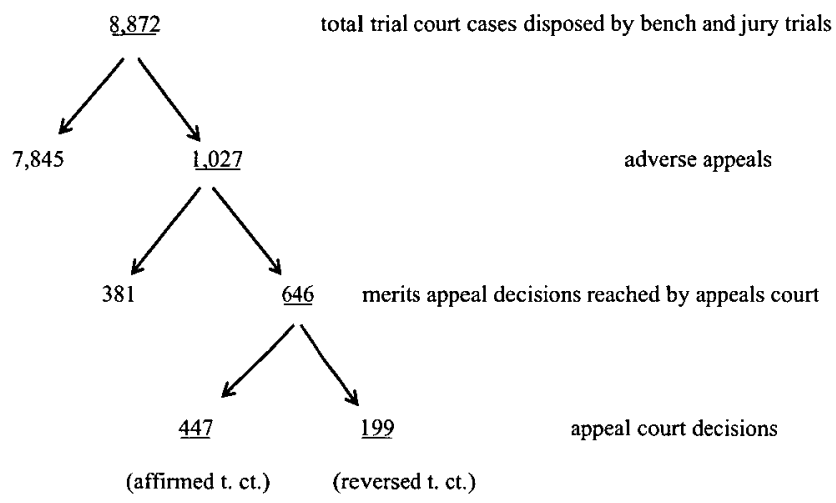

Sources: Civil Justice Survey of State Courts (2005); Civil Justice Survey of Trials on Appeal (2005).

Table 1: State and Federal Civil Trials, Appeals, and Outcomes (2005-2009, 2001-2004, 1988-1997)

\begin{tabular}{|c|c|c|c|c|}
\hline & $\begin{array}{l}\text { Civil } \\
\text { Trials }\end{array}$ & $\begin{array}{c}\text { Appealed } \\
\text { (\%) }\end{array}$ & $\begin{array}{c}\text { Appealed to } \\
\text { Completion (\%) }\end{array}$ & $\begin{array}{l}\text { Reversal } \\
\text { Rate (\%) }\end{array}$ \\
\hline \multicolumn{5}{|c|}{ State $(2005-2009)$} \\
\hline All trials & 8,872 & 11.6 & 7.3 & 30.8 \\
\hline Jury trials & 6,427 & 11.1 & 7.3 & 33.1 \\
\hline Bench trials & 2,445 & 12.9 & 7.4 & 25.0 \\
\hline \multicolumn{5}{|c|}{ Party appealing } \\
\hline Defendant & - & 12.2 & 6.9 & 40.9 \\
\hline Plaintiff & - & 11.4 & 8.0 & 21.0 \\
\hline$N$ & 8,872 & 1,027 & 646 & 199 \\
\hline \multicolumn{5}{|c|}{ State (2001-2004) } \\
\hline All trials & 8,038 & 12.0 & 6.8 & 32.1 \\
\hline Jury trials & 6,165 & 11.4 & 6.6 & 33.7 \\
\hline Bench trials & 1,873 & 14.0 & 7.6 & 27.5 \\
\hline Party appealin & - & & & \\
\hline Defendant & - & 12.7 & 6.6 & 41.5 \\
\hline Plaintiff & - & 11.3 & 7.1 & 21.5 \\
\hline$N$ & 8,038 & 965 & 549 & 176 \\
\hline \multicolumn{5}{|c|}{ Federal (1988-1997) } \\
\hline All trials & 60,605 & 28.7 & 12.2 & 18.4 \\
\hline Jury trials & 31,806 & 28.5 & 11.3 & 20.4 \\
\hline Bench trials & 28,799 & 29.0 & 13.2 & 16.5 \\
\hline \multicolumn{5}{|c|}{ Party appealing } \\
\hline Defendant & - & 31.3 & 8.7 & 32.5 \\
\hline Plaintiff & - & 26.8 & 14.8 & 12.0 \\
\hline$N$ & 60,605 & 17,412 & 7,378 & 1,355 \\
\hline
\end{tabular}

Sources: Civil Justice Survey of State Courts (2001, 2005); Givil Justice Survey of Trials on Appeal (2005); Clermont and Eisenberg (2002:952 tbl.1) (federal). 
imposes additional filters. Only 11.6 percent of the tried civil cases initiated the appeal process (though the percentage is slightly higher if one includes the ambiguous, nonadverse appeals). Finally, fewer cases still ( 7.3 percent) pursued the appeals process to decision. That is, of the cases that initiated the appeals process, fewer than two-thirds $(62.9$ percent) completed at least the first level of the process, disposition by at least one appellate court.

There are strong theoretical and practical reasons to expect these selection effects to contribute to a nonrandom sample of cases on appeal. Expectations theory predicts that objectively strong and weak civil cases will settle or reach conclusion prior to reaching a conclusion at trial ${ }^{52}$ Litigants that take cases to trial do so partly because they can afford to pursue trial litigation and, presumably, because they sense some reasonable level of uncertainty-factual or legal-as to a case's outcome. ${ }^{53}$ This subpool of cases that withstands settlement or withdrawal, motions for directed verdicts and summary judgments, and other dispositions more likely comprises cases whose underlying merits reside somewhere in the "gray middle area" where the legal result is somewhat uncertain. Moreover, a similar set of filters arises anew during the posttrial appeal process. ${ }^{54}$ In all, these various selection filters influence the case stream over time and in a manner that generates a skewed subset of appeals. The data, however, allow us to account for one aspect of the selection processes at work: the decision to undertake an appeal after trial.

\section{Initial Observations-Descriptive Analyses}

We now turn to those cases that initiated the appeals process, explore appeal rates and appellate outcomes, and assess how they vary across trial, party, and case types. The top two panels in Table 1 report the basic pattern of state court appeals in 2005-2009 and 20012004, respectively. ${ }^{55}$ The bottom panel reports federal appeals data for the 1988-1997 period.

\section{A. The Vanishing Appeal?}

If state civil complaints that result in a trial on the merits are becoming increasingly rare over time, ${ }^{56}$ rarer still, as the top panel in Table 1 illustrates, are the 11.6 percent of trial

\footnotetext{
${ }^{52}$ Theodore Eisenberg, Litigation Models and Trial Outcomes in Civil Rights and Prisoner Cases, 77 Geo. L.J. 1567 (1989).

${ }^{53}$ Priest \& Klein, supra note 11.

${ }^{54}$ Priest \& Klein, supra note 11; Richard L. Revesz, Litigation and Settlement in the Federal Appellate Courts: Impact of Panel Selection Procedures on Ideologically Divided Courts, 29 J. Legal Stud. 685 (2000).
}

\footnotetext{
${ }^{55}$ Recall again that the civil litigation sample reported in 2005 was expanded from the 2001 sample to include a subsample of cases from nonurban jurisdictions.
}

${ }^{56}$ Galanter, supra note 5 . 
judgments that initiated an appeal in the most recent (2005) data cohort. Fewer trials still (7.3 percent) resulted in an appellate court decision. Assessing whether the 11.6 percent appeal and the 7.3 percent appeal-to-completion rates are large or small, and how they might trend over time, requires context. Regrettably, detailed time series on state court appeals from trials data are not available.$^{57}$ Our cross-sectional data provide only a snapshot of the state civil appeals world rather than a longitudinal picture of trends over sustained periods of time. With directly relevant data lacking, we turn instead to other sources for context.

One obvious reference point involves the earlier cohort of state appeals data (2001). A comparison between the top and middle panels in Table 1 reveals a relatively stable state appellate context. The percentage of completed trials triggering an appeal (11.6 vs. 12.0) and the percentage of appeals taken to completion (7.3 vs. 6.8) suggest little change from 2001 to 2005. Moreover, results for the composition of the appeals (jury vs. bench trials; plaintiff vs. defendant) as well as the outcomes of the appeals convey overall stability.

Data on federal civil appeals provide an alternative reference point for judgments about state civil appeals data. The bottom panel in Table 1 illustrates a discernible difference in federal and state appellate courts in terms of appeals rates. At first glance, Clermont and Eisenberg's federal appeals rate (28.7 percent) suggests that our state appeals rate (11.6 percent) may be small both in comparative and absolute terms ${ }^{58} \mathrm{~A}$ number of factors, however, may blunt the appeals rate differences in federal and state courts. First, structural differences between the streams of federal and state appeals contribute to different federal and state appeals rates. Important differences in the types of claims pursued in state and federal appellate courts might account for appeals rate differences. For example, to access the federal court system, litigants must either raise a federal question ${ }^{59}$ or plead for damages that exceed $\$ 75,000$ and establish diversity between parties. ${ }^{60}$ Either jurisdictional requirement might route systematically higher-stakes cases into federal courts and away from state courts. Just as higher-stakes cases tend to be litigated to trial more than their lower-stakes counterparts, higher-stakes cases might similarly exert upward pressure on decisions to appeal. ${ }^{61}$ Therefore, if federal trials typically involve higher-stake claims than those pursued in state trials, we should expect the federal appeals rate to exceed the state appeals rate. ${ }^{62}$

\footnotetext{
${ }^{57}$ The best available data on trial court filings and appellate court dispositions are from the National Center for State Courts (NCSC). But the NCSC data do not separately report on appeals of tried cases.
}

${ }^{58}$ Clermont \& Eisenberg, supra note 10.

${ }^{59} 28$ U.S.C. $\$ 1331$ (2006).

${ }^{60} 28$ U.S.C. $\$ 1332(a)(2006)$.

\footnotetext{
${ }^{61}$ Richard A. Posner, Economic Analysis of Law (Little, Brown 1992); Samuel R. Gross \& Kent D. Syverud, Getting to No: A Study of Settlement Negotiations and the Selection of Cases for Trial, 90 Mich. L. Rev. 319 (1991).

${ }^{62}$ Although the intuition that structural differences between federal and state courts might route systematically higher-stakes cases into federal courts strikes us as plausible, it bears noting that the intuition lacks empirical verification. Our data do not permit reliable assessments about the actual case in controversy.
} 
Second, a steady diminution of trial activity over time might also contribute to the differences in federal and state appeals rates presented in Table 1. Marc Galanter's important study of trial activity and rates documents a profound and sustained reduction in civil trial activity in federal and state courts. ${ }^{63}$ In light of a decline in trial activity as a percentage of case filings, one might expect a similar decline in litigants' appetite for posttrial appeals. Insofar as the Clermont and Eisenberg studies of federal appeals involve an earlier time period (1988-1997) than our state appeals studies (2001 and 2005), our finding of a lower state appeals rate might be due to the different time periods of the two studies and capture a downturn in appeals activity over time. ${ }^{64}$ This alternative explanation, however, assumes that federal and state trial and appeals rates trend similarly in both magnitude and direction.

Third, the influence of motor vehicle cases on state courts also contributes to the difference between state and federal appeals rates. Motor vehicle cases account for 33.4 percent of our pool of state trials, by far the most popular case type. Such cases account for a much smaller fraction of federal trials. ${ }^{65}$ As Table 2 illustrates, motor vehicle cases' appeal rate ( 5.0 percent), however, is the lowest across all individual case types. Consequently, the sheer number of motor vehicle cases and their low appeal rate interact in a manner that depresses the overall state appeals rate. Excluding state motor vehicle cases from our sample increases the state appeals rate from 11.6 percent to 14.9 percent and brings it closer to the federal appeals rate ( 28.7 percent). Even after such an exclusion, however, a sizable gap between the state and federal appeals rates persists.

Finally, while the federal appeals rate certainly exceeds the appeals rate in state courts, we also see potentially important differences in the respective reversal rates (or "successful appeals"). In both panels of state court appeals, the overall reversal rates range from 30.8 percent to 32.1 percent. For federal courts, the overall reversal rate was 18.4 percent. Discounting the comparatively higher federal appeals rate ( 28.7 percent) by the comparatively lower reversal rate (18.4 percent) helps bring the effective "successful" federal appeals rate more in line with the effective state court appeals rates.

Regardless of whether one regards the overall state civil appeals rate (11.6 percent) as large or small or how one chooses to contextualize it, the overall appeals rate masks important variation across party and trial types as well as case types. These observed variations in appeals rates largely track variations observed in the federal system. As Table 1 illustrates, defendants who lost at trial were more likely than plaintiffs to initiate an appeal (12.2 percent vs. 11.4 percent). Our findings comport with party appeal rates in the federal context, though Clermont and Eisenberg report a slightly larger gap between defendantand plaintiff-initiated appeals ( 31.3 percent vs. 26.8 percent) ${ }^{66}$ State litigants were more

${ }^{63}$ Galanter, supra note 5 .

${ }^{64}$ Clermont \& Eisenberg, supra note 3; Clermont \& Eisenberg, supra note 10.

${ }^{65}$ Theodore Eisenberg, John Goerdt, Brian Ostrom \& David Rottman, Litigation Outcomes in State and Federal Courts: A Statistical Portrait, 19 Seattle U. L. Rev. 433 (1996).

${ }^{66}$ Clermont \& Eisenberg, supra note 10. 
Table 2: State Appeal and Reversal Rates, by Case Category and Trial Type (2005-2009)

\begin{tabular}{|c|c|c|c|c|c|c|c|c|}
\hline \multirow[b]{2}{*}{ Case Category } & \multicolumn{4}{|c|}{ Appeals } & \multicolumn{3}{|c|}{ Reversal Rates (\%) } & \multirow[b]{2}{*}{$\begin{array}{l}\text { Signif. of } \\
D-P \text { Diff }\end{array}$} \\
\hline & Filed & $\begin{array}{l}\text { Filed } \\
(\%)\end{array}$ & Completed & $\begin{array}{c}\text { Completed } \\
(\%)\end{array}$ & Overall & Defendants & Plaintiffs & \\
\hline All cases & 1,027 & 11.6 & 646 & 62.9 & 30.8 & 40.9 & 21.0 & 0.000 \\
\hline Motor vehicle & 148 & 5.0 & 98 & 66.2 & 20.4 & 31.0 & 12.5 & 0.041 \\
\hline Assault, slander, libel & 45 & 13.5 & 23 & 51.1 & 30.4 & 54.6 & 8.33 & 0.027 \\
\hline Product liability & 34 & 19.1 & 25 & 73.5 & 40.0 & 58.3 & 23.1 & 0.111 \\
\hline Dangerous premises & 66 & 7.6 & 34 & 51.5 & 26.5 & 38.5 & 19.1 & 0.254 \\
\hline Medical malpractice & 137 & 13.8 & 90 & 65.7 & 26.7 & 32.1 & 24.2 & 0.449 \\
\hline Prof. malpractice & 24 & 30.4 & 15 & 62.5 & 6.7 & 10.0 & 0.0 & 1.000 \\
\hline Other tort & 46 & 12.7 & 36 & 78.3 & 33.3 & 42.1 & 23.5 & 0.302 \\
\hline Employment contract & 77 & 23.6 & 44 & 57.1 & 31.8 & 42.9 & 12.5 & 0.049 \\
\hline Fraud & 103 & 20.9 & 71 & 68.9 & 49.3 & 60.5 & 32.1 & 0.029 \\
\hline Lease & 28 & 12.8 & 12 & 42.9 & 33.3 & 37.5 & 25.0 & 1.000 \\
\hline Other contract & 272 & 15.6 & 167 & 61.4 & 30.5 & 37.6 & 21.6 & 0.029 \\
\hline Property & 47 & 15.3 & 31 & 66.0 & 38.7 & 45.5 & 35.0 & 0.705 \\
\hline Tort & 500 & 8.7 & 321 & 64.2 & 25.9 & 36.3 & 18.3 & 0.000 \\
\hline Contract & 480 & 17.3 & 294 & 61.3 & 35.6 & 44.2 & 23.0 & 0.000 \\
\hline Property & 47 & 15.3 & 31 & 66.0 & 38.7 & 45.5 & 35.0 & 0.705 \\
\hline Jury trial & 711 & 11.1 & 466 & 65.5 & 33.1 & 45.9 & 21.8 & 0.000 \\
\hline Judge trial & 316 & 12.9 & 180 & 57.0 & 25.0 & 30 & 18.8 & 0.118 \\
\hline Urban county & 920 & 89.6 & 580 & 63.0 & 30.5 & 40.9 & 20.7 & 0.000 \\
\hline Nonurban county & 107 & 10.4 & 66 & 61.7 & 33.3 & 40.5 & 24.1 & 0.195 \\
\hline$N$ & 1,027 & & 646 & & 199 & & & \\
\hline
\end{tabular}

Notes: The "Reversal Rates (\%)" columns for defendants and plaintiffs are the rates at which an appealing defendant and plaintiff, respectively, achieved appellate reversal or remand of a trial court judgment. The final column, "Signif. of D - P Diff.," tests the statistical difference between the defendants' and plaintiffs' reversal rates using Fisher's exact test.

Source: Civil Justice Survey of Trials on Appeal (2005).

likely to appeal bench than jury trial decisions (12.9 percent vs. 11.1 percent). Clermont and Eisenberg found a numerically small appeal rate gap between trial types (29.0 percent vs. 28.5 percent) ${ }^{67}$ the appeal rate gap between trial types in our study achieved statistical significance. The highest appeals rate combination belonged to defendants who lost at a bench trial. The combination associated with the lowest appeals rate involved plaintiffs who lost in front of a jury.

In addition to party and trial type variation, as Table 2 illustrates, appeal rates also varied, sometimes substantially, across case types. Although 11.6 percent of all state tried cases were appealed, professional (nonmedical) malpractice, employment contracts, and fraud cases were appealed at rates far above the mean (30.4 percent, 23.6 percent, and 20.9 percent, respectively). As previously discussed, motor vehicle cases were the least likely case type to generate an appeal ( 5.0 percent). If differences in case stakes help explain differences in the federal and state appeals rates, similar differences might also explain variations

\footnotetext{
${ }^{67}$ Clermont \& Eisenberg, supra note 10.
} 
in appeals rates across state case types. For example, the appeals rate for professional malpractice claims may exceed that of motor vehicle claims because of differences in the financial stakes contested in such cases.

\section{B. Appeal Outcomes}

Theory and folklore influence perceptions about appeals' outcomes. Selection theory implies that, similar to trial outcomes, appeals outcomes (reverse or affirm) should be roughly similar and distribute equally between plaintiffs and defendants. ${ }^{68}$ Attorney folklore also emphasizes jury verdicts' insulation from reversal by appellate courts. ${ }^{69}$ Neither theory nor folklore, however, satisfactorily explain our major findings. State appeals courts were far more likely to affirm than reverse a trial court decision (69.2 percent vs. 30.8 percent). Moreover, appeals courts were more inclined to reverse jury than judge decisions. Finally, defendants succeeded in reversing adverse trial court decisions almost twice as often as did plaintiffs ( 40.9 percent vs. 21.0 percent).

As noted above, unrefined case-selection considerations suggest that state trials and appeals should approximate 50 percent success for plaintiffs and defendants. At the state trial court level, selection theory reasonably describes the outcome distribution-at least at the aggregate level-as outcomes do not dramatically favor plaintiffs or defendants. ${ }^{70}$ However, aggregate win rates in trial courts mask substantial variation across case types. In 2005, for example, plaintiffs' trial win rates ranged from a high of 89.4 percent (mortgage foreclosure cases) to a low of 15.5 percent (false arrest). ${ }^{71}$

Regardless of how well selection theory might predict state civil trial outcomes, state civil appellate outcomes are not close to 50 percent wins for plaintiffs and defendants. As Table 2 shows, we find an overall 30.8 percent reversal rate. ${ }^{72}$ This rate is closer to the 18.4 percent federal appeals reversal rate Clermont and Eisenberg ${ }^{73}$ found than to the (approximately) 50 percent basic rate that Priest and Klein's selection theory implies. ${ }^{74}$ Thus, the filtering mechanisms and case-type mix that yielded an aggregate trial success rate not too far from 50 percent applied differently in the appeals context. The predominance of

\footnotetext{
${ }^{68}$ Priest \& Klein, supra note 11.

${ }^{69}$ See, e.g., Somerville, supra note 6.

${ }^{70}$ U.S. Dep't of Justice, supra note 39.

${ }^{71}$ U.S. Dep't of Justice, supra note 39.
}

\footnotetext{
${ }^{72}$ We define "reversal" to include full and partial reversals. Any result short of a full affirmance represents an upsetting of the status quo and, at a practical level, upsets the party who won at trial.

${ }^{73}$ Clermont \& Eisenberg, supra note 10.

${ }^{74}$ The approximately 70 percent higher rate of reversal of state trials than federal trials warrants future study. The higher state reversal rate is not a consequence of a different mix of case types because only one category of federal cases, fraud, achieves the overall state reversal rate of about 32 percent. No other federal case category has a reversal rate as high as 30 percent. See Clermont \& Eisenberg, supra note 10, at 954-55 tbl.2.
} 
affirmance over reversal is comforting since high reversal rates would suggest high trial court error rates or troublingly high rates of appellate court and trial court disagreement.

Even more dramatic than the overall reversal rate departing 50 percent is the starkly asymmetric distribution of appellate outcomes between plaintiffs and defendants and jury and judge trials. As Tables 1 and 2 show, defendants were far more likely than plaintiffs (40.9 percent vs. 21.0 percent) to successfully reverse an adverse trial outcome. Indeed, from the perspective of a plaintiff victorious at trial, the appeals process offered a chance to retain victory not far from what a coin flip would predict. For defendants, by contrast, trial victories were far more secure. Moreover, as Table 2 illustrates, the reversal rate difference substantially favors defendants in both judge and jury trials and in all case types. As the final column in Table 2 illustrates, the overall defendant and plaintiff reversal rates difference (40.9 percent vs. 21.0 percent) achieved statistical significance, along with various case types.

Table 2 also makes clear the level of variation across case types in terms of the defendants' appellate advantage. In three of the 12 case types considered, the defendants' reversal rate exceeded 50 percent. In contrast, in none of the case types considered did the plaintiffs' reversal rate exceed 35 percent. Thus, defendants emerged from the state appellate process in a far better position than they left the trial court.

Finally, although judge trials were more likely to involve an appeal than jury trials (12.9 percent vs. 11.1 percent), Table 2 shows that, contrary to conventional wisdom, appellate courts were kinder to judge than jury decisions (25 percent vs. 33.1 percent reversal rate). Moreover, reversal rates favoring defendants persist across all trial types with many of these asymmetrical differences achieving statistical significance.

On balance, our findings so far are consistent with prior federal ${ }^{75}$ and state ${ }^{76}$ court research, and they suggest an appeals court tilt favoring defendants, particularly defendants that lost a jury trial. Because the evidence is descriptive, however, it can easily mask confounding factors, including the trial court's behavior, the decision to appeal, and posttrial settlement conduct. To explore whether our results are an artifact of factors not considered, we proceed to more formally model both the decision to appeal and the appellate case outcome.

\section{Assessing Competing Explanations for a DeFEndant Advantage}

As Section II suggests, theory and prior scholarship advance two plausible explanations for our asymmetrical appellate outcomes. More formal models-and empirical testing of those models-should inform assessments about each explanation's persuasiveness. Given the observational nature of our data, we cannot conclusively establish causal inference relating

\footnotetext{
${ }^{75}$ Clermont \& Eisenberg, supra note 3; Clermont \& Eisenberg, supra note 10; Eisenberg \& Farber, supra note 24.

${ }^{76}$ Eisenberg \& Heise, supra note 4; Farole \& Cohen, supra note 4.
} 
to the asymmetric reversal rate. Nevertheless, the asymmetrical distribution of appeals outcomes warrants a more statistically sophisticated analyses. The complete trial outcome data available allow us the unusual opportunity to account for the flow of cases to appellate courts as well as the appellate outcomes.

Efforts to model appellate outcomes must account, first, for any selection bias generated by the predicate decision to appeal a trial court verdict and, second, for the outcome of the appeal itself. If appellate courts see plaintiff and defendant posttrial appeals that differ in quality, as Eisenberg and Farber's study suggests, the decision to appeal may fuel unbalanced appellate outcomes. ${ }^{77}$ To account for a selection effect generated by the predicate decision to pursue (and complete) an appeal and, in turn, how it might influence the outcome of an appealed case, we used a Heckman probit selection model. Insofar as technical support for the presence of selection effects is mixed, however, we also report results from a mixed effects logistic regression model. Finally, as one test of robustness we report results from two versions (parsimonious ("slim") and "full") of both the Heckman and mixed effects models.

\section{A. Modeling the Decision to Appeal and the Appeal Outcome}

What variables should an appellate model include? With respect to the decision to appeal, parties' perceptions (or misperceptions) about how appellate courts react to jury trials compared to bench trials, and to plaintiff trial court wins compared to defendant wins, likely inform litigants. To account for this possibility, we interact and include dummy variables signaling whether a case was tried to a jury or judge, and whether a plaintiff or defendant prevailed.

We also anticipate that a state's and particular case type's "reversal culture" inform litigants' decisions about whether to pursue an appeal. For each state and case category we computed an overall reversal rate. For example, the overall reversal rates in Minnesota and Georgia were 25 percent and 60 percent, respectively. Similarly, reversal rates for various case types ranged from 49.3 percent (employment contract cases) to 6.7 percent (professional malpractice cases). Holding all else constant, we expect that parties seeking to reverse a trial court decision would be more reluctant to pursue an appeal in states or involving case types with comparatively lower reversal rates.

In addition to varied reversal rates, the case type itself also exercises important influence over other factors. For example, case types influence the routing of cases to either judges or juries and display sometimes sharply different trial outcomes. ${ }^{78}$ As well, case types also influence various trial facets, such as case disposition time ${ }^{79}$ Given the wide-ranging

\footnotetext{
${ }^{77}$ Eisenberg \& Farber, supra note 24.

${ }^{78}$ Clermont \& Eisenberg, supra note 33

${ }^{79}$ Michael Heise, Justice Delayed?: An Empirical Analysis of Civil Case Disposition Time, 50 Case W. Res. L. Rev. 813 (2000).
} 
influence of case types on the civil justice system, we also anticipate that case types influence the appeals process. We therefore include a dummy variable in the full model specifications for each of our 12 case types.

Insofar as individuals, corporations, and governments differ in their appetite for and behavior in litigation, it is reasonable to assume that such variation persists into the appeals process. ${ }^{80}$ To account for this variation, we use dummy variables to identify cases involving corporate-plaintiffs, corporate-defendants, and governmental-plaintiffs. ${ }^{81}$ The litigant characteristics are salient regardless of the trial outcome. For example, to the extent that individual litigants believe that corporations behave differently in the litigation context, such differences would presumably present regardless of whether the corporation won or lost at trial. Moreover, because litigants' decisions about whether to appeal may evolve over time, we include the year the lawsuit was initially filed to help control for any linear time trend in our data. Finally, as one crude proxy for the financial "stakes" of an appeal, we include the total damages awarded (in constant dollars). We believe that higher damages cases will be more prone to an appeal than lower damages cases.

Efforts to model the outcome of an appeal call for a similar, though slightly different, set of independent variables. Analyzing the determinants of appellate court outcomes (reversals) is our principal interest and, among the array of plausible independent variables, our primary focus involves trial type (judge vs. jury) and trial outcome (defendant or plaintiff victory). Our descriptive results, presented in Tables 1 and 2, suggest that appellate reversals were more likely for defendants that lost in jury trials. Other independent variables, such as case types, party types, and year appeal filed, are obvious candidates for inclusion given these variables' import for the decision to file an appeal as well as trial court outcome. To account for possible state-level effects on the appellate outcome, we include dummy variables for each state in the full version of the Heckman model (Model 2). Finally, because outcomes of individual appeals within a county might not be independent of one another, we treat appeals as clustered at the county level, resulting in adjusted standard errors.

\section{B. Results}

Table 3 reports results of the key variables in the appeals outcome portion of our selection and mixed effects models. The selection model includes all tried cases. Evidence of a selection effect from our two versions of the Heckman models (Models 1 and 2) is mixed and sensitive to model specifications. Specifically, the rho test statistic achieves statistical significance in the parsimonious (Model 1) but not the full (Model 2) model. Moreover, plaintiff jury trial victories achieved statistical significance in all but one model specification

\footnotetext{
${ }^{80}$ Theodore Eisenberg \& Henry S. Farber, The Government as Litigant: Further Tests of the Case Selection Model, 5 Am. L. \& Econ. Rev. 94 (2003). ${ }^{81}$ We focus on these particular pairings in an effort to tether this study to prior studies. In any event, the inclusion of
other pairings does not disturb our core findings.
} 
Table 3: Selection and Mixed Effects Models of State Appellate Outcome (Reversal) and Decision to Appeal

\begin{tabular}{|c|c|c|c|c|c|c|c|c|}
\hline & $\begin{array}{c}\text { (I) } \\
\text { (Slim) } \\
\text { Selection }\end{array}$ & (s.e.) & $\begin{array}{c}(2) \\
(F u l l) \\
\text { Selection }\end{array}$ & (s.e.) & $\begin{array}{c}\text { (3) } \\
\text { (Slim) } \\
\text { Mixed Effects }\end{array}$ & (s.e.) & $\begin{array}{c}\text { (4) } \\
(\text { Full }) \\
\text { Mixed Effects }\end{array}$ & (s.e.) \\
\hline \multicolumn{9}{|l|}{ Appeal Outcome (Reversal) } \\
\hline \multicolumn{9}{|l|}{ Trial outcomes } \\
\hline Def. won bench trial & (ref) & - & (ref) & - & (ref) & - & (ref) & - \\
\hline Plaintiff won bench trial & 0.202 & $(0.151)$ & 0.218 & $(0.168)$ & 0.259 & $(0.323)$ & 0.398 & $(0.329)$ \\
\hline Def. won jury trial & 0.119 & $(0.169)$ & 0.260 & $(0.395)$ & 0.490 & $(0.304)$ & $0.754^{*}$ & $(0.319)$ \\
\hline Plaintiff won jury trial & $0.510^{* *}$ & $(0.162)$ & 0.759 & $(0.441)$ & $1.045^{* *}$ & $(0.288)$ & $1.484^{* *}$ & $(0.298)$ \\
\hline \multicolumn{9}{|l|}{ Case Types } \\
\hline Motor vehicle & - & & (ref) & - & - & & (ref) & - \\
\hline Intentional tort & - & & 0.072 & $(0.590)$ & - & & $1.175^{* *}$ & $(0.450)$ \\
\hline Product liability & - & & 0.204 & $(0.720)$ & - & & $2.058 * *$ & $(0.420)$ \\
\hline Dangerous premises & - & & 0.118 & $(0.319)$ & - & & 0.466 & $(0.413)$ \\
\hline Medical malpractice & - & & 0.263 & $(0.642)$ & - & & $1.639 * *$ & $(0.322)$ \\
\hline Prof. malpractice & - & & -1.079 & $(1.017)$ & - & & 0.384 & $(1.043)$ \\
\hline Other tort & - & & 0.452 & $(0.745)$ & - & & $1.637 * *$ & $(0.378)$ \\
\hline Employment contract & - & & 0.055 & $(0.911)$ & - & & $1.701 * *$ & $(0.372)$ \\
\hline Fraud & - & & 0.641 & $(0.968)$ & - & & $2.442^{* *}$ & $(0.311)$ \\
\hline Lease, mortgage & - & & 0.114 & $(0.711)$ & - & & 1.139 & $(0.580)$ \\
\hline Other contract & - & & 0.246 & $(0.765)$ & - & & $1.574 * *$ & $(0.305)$ \\
\hline Property & - & & - & - & - & & $2.075^{* *}$ & $(0.423)$ \\
\hline Damages (ttl.) & 0.000 & $(0.000)$ & 0.000 & $(0.000)$ & $0.000^{* *}$ & $(0.000)$ & $0.000^{*}$ & $(0.000)$ \\
\hline \multicolumn{9}{|l|}{ Litigant Characteristics } \\
\hline Government plaintiff & 0.574 & $(0.327)$ & 0.537 & $(0.428)$ & $1.192^{* *}$ & $(0.442)$ & 0.595 & $(0.491)$ \\
\hline Corporate plaintiff & -0.032 & $(0.104)$ & 0.023 & $(0.224)$ & $0.712^{* *}$ & $(0.184)$ & 0.372 & $(0.197)$ \\
\hline Corporate defendant & -0.001 & $(0.115)$ & 0.088 & $(0.170)$ & $0.570^{* *}$ & $(0.153)$ & $0.343^{*}$ & $(0.174)$ \\
\hline Constant & -0.105 & $(0.451)$ & -1.050 & (2.894) & $-5.079 * *$ & $(0.316)$ & $-6.409 * *$ & $(0.386)$ \\
\hline$N$ & - & & - & & 646 & & 646 & \\
\hline Log likelihood & - & & - & & -904.72 & & -858.37 & \\
\hline \multicolumn{9}{|l|}{ Decision to Appeal } \\
\hline \multicolumn{9}{|l|}{ Trial outcomes } \\
\hline Def. won bench trial & $(\mathrm{ref})$ & - & (ref) & - & (ref) & - & $(\mathrm{ref})$ & 一 \\
\hline Plaintiff won bench trial & -0.020 & $(0.073)$ & -0.020 & $(0.073)$ & -0.034 & $(0.137)$ & -0.034 & $(0.137)$ \\
\hline Def. won jury trial & $0.207^{*}$ & $(0.085)$ & $0.207^{*}$ & $(0.084)$ & $0.359^{* * *}$ & $(0.134)$ & $0.359^{* *}$ & $(0.134)$ \\
\hline Plaintiff won jury trial & $0.173^{*}$ & $(0.085)$ & $0.174^{*}$ & $(0.084)$ & $0.287^{*}$ & $(0.130)$ & $0.287 *$ & $(0.130)$ \\
\hline State appeals rev. rate & 0.003 & $(0.003)$ & 0.001 & $(0.003)$ & 0.000 & $(0.007)$ & -0.003 & $(0.007)$ \\
\hline Case type appeals rev. rate & $0.034 * *$ & $(0.005)$ & $0.034^{* *}$ & $(0.004)$ & $0.063^{* *}$ & $(0.007)$ & $0.063^{* *}$ & $(0.007)$ \\
\hline \multicolumn{9}{|l|}{ Case types } \\
\hline Motor vehicle & (ref) & - & (ref) & - & $($ ref $)$ & - & $($ ref) & 一 \\
\hline Intentional tort & $0.176^{*}$ & $(0.089)$ & 0.186 & $(0.098)$ & $0.357^{*}$ & $(0.175)$ & $0.357 *$ & $(0.175)$ \\
\hline Product liability & -0.040 & $(0.184)$ & -0.049 & $(0.190)$ & 0.011 & $(0.225)$ & 0.011 & $(0.225)$ \\
\hline Dangerous premises & -0.061 & $(0.085)$ & -0.060 & $(0.087)$ & -0.113 & $(0.149)$ & -0.113 & $(0.149)$ \\
\hline Medical malpractice & $0.296 * *$ & $(0.075)$ & $0.294 * *$ & $(0.074)$ & $0.566^{* *}$ & $(0.126)$ & $0.566^{* *}$ & $(0.126)$ \\
\hline Prof, malpractice & $1.419^{* *}$ & $(0.174)$ & $1.546^{* *}$ & $(0.164)$ & $2.664 * *$ & $(0.316)$ & $2.664 * *$ & $(0.316)$ \\
\hline Other tort & 0.076 & $(0.103)$ & 0.049 & $(0.103)$ & 0.066 & $(0.174)$ & 0.066 & $(0.174)$ \\
\hline Employment contract & $0.470^{* * *}$ & $(0.101)$ & $0.505^{* *}$ & $(0.096)$ & $0.817^{* *}$ & $(0.149)$ & $0.817^{* *}$ & $(0.149)$ \\
\hline Fraud & -0.149 & $(0.098)$ & -0.185 & $(0.095)$ & $-0.387^{*}$ & $(0.179)$ & $-0.387 *$ & $(0.179)$ \\
\hline Lease, mortgage & 0.065 & $(0.112)$ & 0.079 & $(0.124)$ & 0.195 & $(0.217)$ & 0.195 & $(0.217)$ \\
\hline Other contract & - & - & - & - & - & - & - & - \\
\hline Property & - & - & - & - & - & - & - & - \\
\hline Year case filed & $-0.051^{*}$ & $(0.020)$ & $-0.051^{*}$ & $(0.020)$ & $-0.118^{* *}$ & $(0.025)$ & $-0.118^{* *}$ & $(0.025)$ \\
\hline Damages $(\mathrm{t} t \mathrm{l})$ & $0.000^{*}$ & $(0.000)$ & $0.000^{*}$ & $(0.000)$ & $0.000^{*}$ & $(0.000)$ & $0.000^{*}$ & $(0.000)$ \\
\hline \multicolumn{9}{|l|}{ Litigant Characteristics } \\
\hline Government plaintiff & 0.120 & $(0.248)$ & 0.130 & $(0.249)$ & 0.228 & $(0.432)$ & 0.228 & $(0.432)$ \\
\hline Corporate plaintiff & $0.167^{* *}$ & $(0.063)$ & $0.166^{* *}$ & $(0.062)$ & $0.322^{* *}$ & $(0.102)$ & $0.322 * *$ & $(0.102)$ \\
\hline
\end{tabular}


Table 3 continued

\begin{tabular}{|c|c|c|c|c|c|c|c|c|}
\hline & $\begin{array}{c}\text { (1) } \\
\text { (Slim) } \\
\text { Selection }\end{array}$ & (s.e.) & $\begin{array}{c}\text { (2) } \\
(F u l l) \\
\text { Selection }\end{array}$ & (s.e.) & $\begin{array}{c}\text { (3) } \\
\text { (Slim) } \\
\text { Mixed Effects }\end{array}$ & (s.e.) & $\begin{array}{c}\text { (4) } \\
\text { (Full) } \\
\text { Mixed Effects }\end{array}$ & (s.e.) \\
\hline Corporate defendant & $0.115^{* *}$ & $(0.040)$ & $0.115^{* *}$ & $(0.040)$ & $0.196^{*}$ & $(0.082)$ & $0.196^{*}$ & $(0.082)$ \\
\hline Constant & $99.35^{*}$ & $(39.706)$ & $100.50^{*}$ & $(39.885)$ & $231.31 * *$ & $(50.276)$ & $231.31 * *$ & $(50.276)$ \\
\hline Rho & $-0.587^{* *}$ & $(0.167)$ & -0.264 & $(1.108)$ & - & - & - & - \\
\hline$N$ & 8,544 & & 8,544 & & 8,544 & & 8,544 & \\
\hline Log likelihood & -3300.92 & & -3269.35 & & -2795.87 & & -2795.87 & \\
\hline County-level cluster & Yes & & Yes & & No & & No & \\
\hline State effects & No & & No & & Yes & & Yes & \\
\hline State dummy variables & No & & Yes & & No & & No & \\
\hline
\end{tabular}

Notes: We report parsimonious (slim) (Model 1) and full (Model 2) selection and mixed effects (Models 3 and 4) models of appeal outcome and decision to appeal equations. Dependent variable in appeal outcome equation and model is reversal of trial court decision; dependent variable in decision to appeal equation and model is whether an appeal was filed. Robust standard errors are in parentheses. ${ }^{*} p<0.05,{ }^{*} p<0.01$. We estimated the models using the "heckprob" and "xtmelogit" commands in Stata (v.12.1).

Source: Civil Justice Survey of State Courts (2005); Civil Justice Survey of Trials on Appeal (2005).

(Model 2). When we focus only on jury trials, a test of the difference between the dummy variables DEFENDANT WON JURY TRIAL and PLAINTIFF WON JURY TRIAL achieved statistical significance in both Heckman model specifications. Overall, results from the Heckman models provide mixed evidence of differences in how appeals courts treat defendant and plaintiff trial court victories. However, results from the Heckman models are sensitive to model specifications. As well, the unavailability of such key explanatory variables as a litigant's motivation to appeal and available resources further limits the selection model results.$^{82}$ Consequently, to assess our results' robustness we also consider results from mixed effects models, which display more stability. Notably, plaintiff jury trial victories were systematically more prone to reversal in both versions of our mixed effects models. Our overall finding of a jury trial tilt favoring plaintiffs refines and provides helpful granularity to Farole and Cohen's similar findings of a trial court tilt favoring plaintiffs. ${ }^{83}$

For jury trials, the finding of higher reversal rates of plaintiff trial victories is highly statistically significant in three of the four specifications from the two different models. For bench trials, the positive coefficients for PLAINTIFF wON BENCH TRIAL suggest a similar pro-defendant direction. So the defendant advantage persists in the models, but more strongly in jury trials. Overall, the results imply that jury trials are more prone to reversal than judge trials. The PLAINTIFF wON JURY TRIAL coefficient is larger than the PLAINTIFF WON BENCH TRIAL coefficient in all model specifications. Although achieving statistical significance in one instance, the DEFENDANT WON JURY TRIAL coefficient is consistently positive relative to the reference category of DEFENDANT WON BENCH TRIAL. We find that results from the mixed effects model specifications, presented in Table 3 , more clearly

\footnotetext{
${ }^{82}$ For an alternative empirical specification (logistic regression), see Farole \& Cohen, supra note 48, at $30-33$.
}

${ }^{83}$ Farole \& Cohen, supra note 4. 
comport with the descriptive results evidencing important differences between plaintiff and defendant reversal rates and a more modest difference between judge trial and jury trial reversal rate.

\section{Discussion}

Both the attitudinal and the selection effect hypotheses find some degree of support from the results in Table 3 . With respect to the attitudinal explanation, results from the regression models provide general support for the earlier descriptive findings and are consistent with an appellate court tilt favoring defendants, especially defendants that lost a jury trial. With respect to selection effects, while results from our parsimonious selection model (Column 1) provide support, the full model (Column 2) does not. Obviously, modelspecific implications warrant unusually cautious interpretation. At the very least, our results preclude a conclusion that selection effects are not present, particularly in light of our descriptive results. At the same time, however, it is also clear that selection effects alone cannot fully account for appellate outcomes. While we do not doubt the presence of selection effects (as results in Column 1 imply), it might be that the effect is comparatively small or eludes our model or data. On this point, results from the 2005 appeals data diverge slightly from our prior findings using 2001 appeals data in that the latter provided somewhat less support for the selection effect hypothesis. ${ }^{84}$

\section{Implications for the Attitudinal Hypothesis}

A plaintiff jury trial victory correlates with an appeals court reversal at a statistically significant level in three of our four model specifications. This finding comports with what the descriptive analyses imply, as well as with prior research on federal and state appeals. Clermont and Eisenberg found a federal court appeals outcome tilt favoring defendants who lost either judge or jury trials. ${ }^{85}$ Although our findings are consistent with these federal appeals findings, our results are narrower in that they only highlight defendant jury losses at trial.

Do these findings imply that juries exert a level of pro-plaintiff bias that accounts for the overall perceived pro-plaintiff bias at the trial court level? This scenario is unlikely, especially insofar as trial court judges retain the legal authority to override jury decisions in civil cases. As well, a considerable and growing empirical literature suggests that, in general, judges and juries act in comparable ways when confronted with comparable cases. ${ }^{86}$ If they

\footnotetext{
${ }^{84}$ Eisenberg \& Heise, supra note 4 , at 142-43, 145-48.

${ }^{85}$ Clermont \& Eisenberg, supra note 3; Clermont \& Eisenberg, supra note 10.

${ }^{8}$ Harry Kalven \& Hans Zeisel, The American Jury (Little, Brown 1966); Theodore Eisenberg, Paula L. Hannaford-Agor, Valerie P. Hans, Nicole L. Waters, G. Thomas Munsterman, Stewart J. Schwab \& Martin T. Wells, Judge-Jury Agreement in Criminal Cases: A Partial Replication of Kalven and Zeisel's American Jury, 2 J. Empirical Legal Stud. 171 (2005); Theodore Eisenberg, Paula L. Hannaford-Agor, Michael Heise, Neil LaFountain, G. Thomas Munsterman, Brian Ostrom \& Martin T. Wells, Juries, Judges, and Punitive Damages: Empirical Analyses Using the Civil Justice Survey of State Courts 1992, 1996, and 2001 Data, 3 J. Empirical Legal Stud. 263 (2006).
} 
do, we are left to explain why the appellate process treats judge and jury decisions, in general, and plaintiff and defendant jury trial outcomes, in particular, differently. Of course, in addition to a trial court tilt favoring plaintiffs, another logical possibility is that appellate courts possess a pro-defendant bias. Finally, Eisenberg and Farber identify a third possibility and attribute the asymmetric success on appeal to plaintiffs' greater appetite for pursuing lower-quality litigation. ${ }^{87}$

Our data and analyses preclude firm assessments of the three possible explanations for the asymmetric appellate outcomes. Whether the observed higher plaintiff reversal rate flows from trial courts favoring plaintiffs, appellate courts favoring defendants, plaintiffs pursuing lower-quality appeals, or some combination of all three remains unclear. Findings from other research that focuses on just this question (i.e., whether the trial courts exhibit bias or whether appeals courts assume trial court bias), however, provide little support for the actual trial court bias explanation. ${ }^{88}$ Because appeals court systematic disagreement with trial courts is strongest for jury verdicts favoring plaintiffs, combined with aggregate trial court decisions that have not been demonstrated to favor plaintiffs over defendants, the interpretation that appellate court misperceptions about jurors' bias toward plaintiffs is more plausible than trial court bias. To be clear, we do not propose a conspiracy theory of concerted action by appellate judges; instead, we only suggest that appellate judges may entertain some of the same misperceptions about trial court outcomes as the general populace and that these misperceptions influence appellate outcomes. Moreover, Eisenberg and Farber argue that plaintiffs' appetite for pursuing lower-quality appeals explains the asymmetric appeals outcomes. ${ }^{89}$ Assessing this possibility's explanatory power in the state context, however, is not possible with our data. Consequently, until more data emerge that speak to whether plaintiffs and defendants pursue different quality appeals, our conjectures on this possibility remain conjectures.

\section{E. Implications for Selection Hypothesis}

Our results also provide limited support for a selection hypothesis as an alternative or, more accurately, complementary explanation for appellate outcomes. If selection effects alone were driving the appellate outcome pattern, one might expect more heterogeneity in that pattern. Selection-based models, such as those explored by Kessler, Meites, and Miller, employ case-category-level differences, such as varying stakes, to help account for selection effects. ${ }^{90}$ But, as noted above, Table 2 shows a strikingly consistent anti-plaintiff pattern

\footnotetext{
${ }^{87}$ Eisenberg \& Farber, supra note 24, at 80.

${ }^{88}$ Richard Lempert, Why Do Juries Get a Bum Rap? Reflections on the Work of Valerie Hans, 48 DePaul L. Rev. 453 (1998); Michael J. Saks, Public Opinion About the Givil Jury: Can Reality be Found in Illusions? 48 DePaul L. Rev. 221 (1998); Neil Vidmar, The Performance of the American Civil Jury: An Empirical Perspective, 40 Ariz. L. Rev, 849 (1998).
}

${ }^{89}$ Eisenberg \& Farber, supra note 24.

${ }^{90}$ Daniel Kessler, Thomas Meites \& Geoffrey Miller, Explaining Deviations from the Fifty-Percent Rule: A Multimodal Approach to the Selection of Cases for Litigation, 25 J. Legal Stud. 233 (1996). 
across many case categories. More important, however, is that plaintiffs, whose hypothesized higher case stakes should make them more selective about what cases to push to trial, should be equally careful about only pushing strong cases on appeal. ${ }^{91}$ If so, appeal reversal rates for plaintiffs would approximate the defendants' reversal rate, if not exceed it. As Table 2 shows, however, this was not the case as defendants enjoyed a far higher appeals reversal rate than plaintiffs (40.9 percent vs. 21.0 percent), and the difference in defendants' and plaintiffs' reversal rates was highly significant. One explanation for differences in plaintiff and defendant reversal rates focuses on the types of cases plaintiffs select for appeal. Specifically, in their study of federal appeals, Eisenberg and Farber find evidence suggesting that plaintiffs pursue litigation where they are comparably more likely to lose. ${ }^{92}$

Results from our parsimonious selection (Heckman) model (Model 1) provide limited technical support for the selection hypothesis. Rho $(\rho)$, a measure of the correlation in the error term in the separate selection and outcome equations, achieves statistical significance. Consequently, one can reject the hypothesis that the error terms from the selection and outcome equations are uncorrelated. We resist placing too much analytical weight on this finding, however. Multi-equation selection models are highly sensitive to specification error. Small changes in the selection model can substantially change outcome estimates. ${ }^{93}$ Moreover, we likely do not have the optimal set of variables to control for both selection and the second-stage outcome. Finally, although separate mixed effects models would be appropriate if rho was not significant, results from mixedeffects models are quite similar to our results from our Heckman selection models. The consistent results across various model specifications enhance our confidence in our core findings.

We also are mindful that our findings only indirectly challenge the selection effect hypothesis. At the level of general theory, plaintiffs and defendants face similar (albeit not identical) economic incentives. These incentives should discipline plaintiffs and their attorneys and discourage weak cases. To the extent that the litigation process itself discourages case filings, ${ }^{94}$ the pool of claims that begins the litigation process might be systematically stronger than the universe of potential legal claims. As well, our study involves appealed cases. By definition, these cases have persisted through the entire trial process, including the pretrial motion stage, which, by design, also helps screen out extreme cases favoring either party. Despite our pool of appealed cases having survived multiple layers of filtering, we nonetheless find evidence of a potential pro-defendant

\footnotetext{
${ }^{91}$ Although the economics of appeals differ substantially from the economics of trials, appeals are not costless.

${ }^{92}$ Eisenberg \& Farber, supra note 24.

${ }^{93}$ Derek C. Briggs, Causal Inference and the Heckman Model, 29 J. Educ. \& Behav. Stat. 397 (2004).

${ }^{94}$ David M. Trubek, Austin Sarat, William L.F. Felstiner, Herbert M. Kritzer \& Joel B. Grossman, The Costs of Ordinary Litigation, 31 UCLA L. Rev. 72 (1983).
} 
appellate court tilt. To be sure, plausible counterarguments-especially those that our data and research design do not squarely address-warrant careful consideration. Selection theory proponents may suggest that plaintiffs start with systematically weaker cases and then litigate them less effectively than defendants. ${ }^{95}$ While such claims may not be theoretically persuasive, Eisenberg and Farber's findings suggest that plaintiffs might press systematically weaker cases (though Eisenberg and Farber do not address plaintiffs' litigation efficaciousness). ${ }^{96}$

Further complicating selection theory's relevance for our results is that appellate outcomes that systematically favor defendants that lost at a jury trial arise in our parsimonious selection model but not in our full selection model. Again, multi-equation selection models are notoriously sensitive to model specification, and mixed results in our selection models may simply reflect this sensitivity. That a pro-defendant tilt emerged in both versions of our mixed effects models, however, increases our confidence about a prodefendant tilt at the appellate level.

\section{F. Other Results}

Although our discussion focuses on one particular set of independent variables-trial outcomes-and their implications for competing explanations for asymmetric appellate outcomes, three other notable results warrant attention. First, when it came to the decision to appeal, case-type appeals reversal rates persistently achieved statistical significance. This finding in our models comports with the descriptive results in Table 2, illustrating important variation in reversal rates across various case types. Second, independent of a case-type appeals reversal rate, certain case types also emerged as particularly prone to appeal. As Table 3 illustrates, the presence of malpractice (both medical and professional) and employment contract claims increased the likelihood of an appeal.

Third, a corporate presence-either through a corporate defendant or, to a slightly lesser extent, corporate plaintiff-increased the probability of an appeal. This finding implies that corporate entities were more able (or willing) to participate in the appeals process. To the extent that these corporate entities were more experienced with litigation as repeat players, such litigants may have benefited from a comparative advantage in terms of managing the appeals process. Suggestions about corporate litigants' access to wealth and litigation experience must remain mere suggestions, however, as they extend beyond our data.

\footnotetext{
${ }^{95}$ One limitation on interpreting both federal and state court plaintiff-defendant asymmetric success on appeal is that the reversal rate is in part a function of what one believes the objectively correct trial win rate should be. If the objectively correct trial win rate in a case category differs from 50 percent, then one expects asymmetric plaintiff and defendant reversal rates on appeal. (See Eisenberg, supra note 3; Bruce D. Spencer, Estimating the Accuracy of Jury Verdicts, 4 J. Empirical Legal Stud. 305 (2007), for a discussion.)
}

${ }^{96}$ Eisenberg \& Farber, supra note 24. 
Figure 2: Relation between plaintiff success at trial and on appeal.

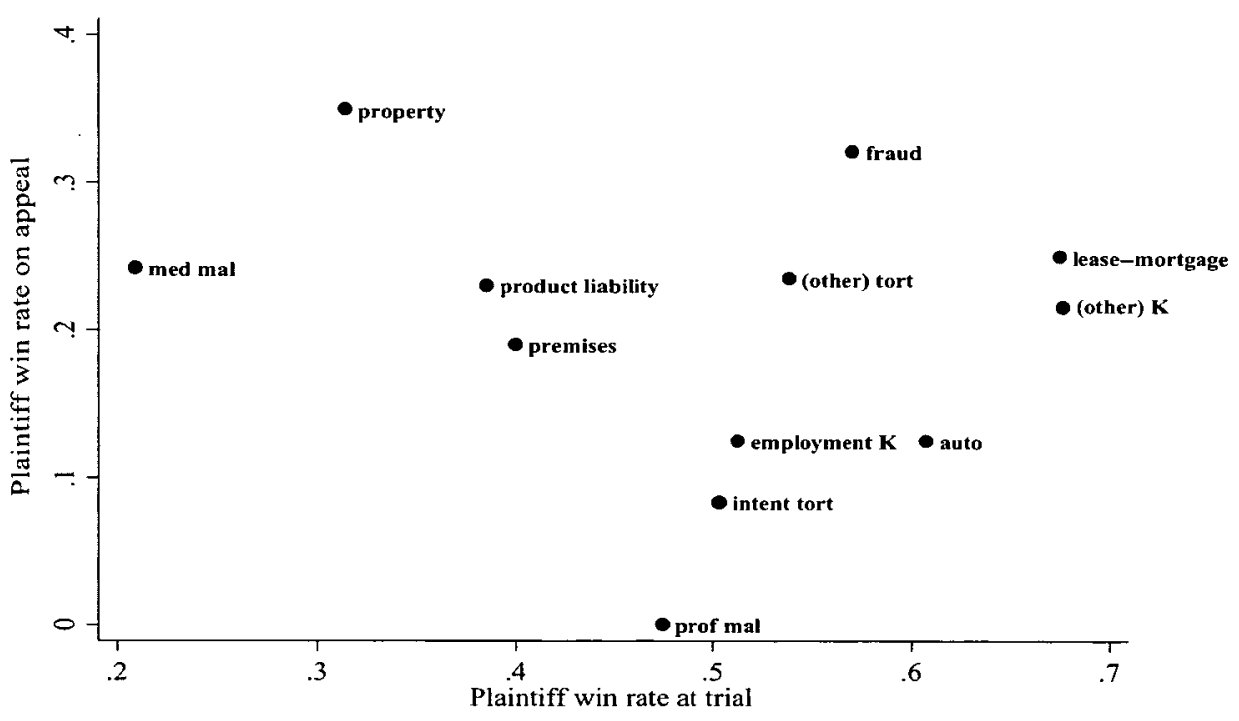

Source: Civil Justice Survey of State Courts (2005); Civil Justice Survey of Trials on Appeal (2005).

\section{G. The Relation Between Plaintiff Success at Trial and on Appeal}

Table 3 shows significant case category effects for the decision to appeal and, in the mixed effects full model, in the outcome on appeal. Yet cases appealed are a small subset of the cases tried and the selection parameter, rho, provides mixed guidance about whether selection effects are important to the appellate results.

Regardless of whether selection effects influence appellate outcome results, it is of independent interest to assess whether, in the full sample of trials, success at trial is associated with success on appeal. Figure 2 shows, on its $\mathrm{x}$-axis, the plaintiff trial success rate and, on its $y$-axis, the plaintiff appeal success rate for the 11 case categories with at least 20 appellate outcomes. The success rate on appeal is a blended success rate that combines plaintiffs as appellants and appellees. The figure shows no noticeable trend. Relative success at one level is not associated with relative success at the next level. For example, property cases have one of the lowest plaintiff trial win rates but have the highest plaintiff win rate on appeal. Fraud plaintiffs do fairly well at trial and on appeal. Medical malpractice plaintiffs fare worst at trial and have more moderate outcomes on appeal. Automobile accident plaintiffs fare relatively well at trial but not on appeal.

These results suggest caution in inferring the relative success of a case category at one court level from its relative success at another level. The results contrast with findings within the trial court level in federal court. In those data, plaintiffs in case categories that fare relatively well at one stage of litigation also fare relatively well at other stages of litigation. The decision to appeal and the treatment of cases on appeal yield a different ranking of plaintiff success than does success at trial. 


\section{Conclusion}

This study extends earlier analyses of appeals from state court trials and the degree to which state appellate court decisions and opinions reflect trial-level activity. Only 7.3 percent of tried state civil cases are appealed to conclusion at any appellate level. This is lower than the approximately 12 percent rate for federal litigation found in prior studies covering a different time period. Appeal and reversal rates differ substantially across case types and reach or exceed 50 percent of defendant appeals in five case categories, including employment litigation.

While state court reversal rates are noticeably higher than federal court reversal rates, state appellate courts, like federal courts, have a greater propensity to overturn jury rather than judge verdicts and plaintiff trial victories more than defendant trial victories. With respect to these asymmetric reversal rates, our findings favor an attitudinal rather than selection explanation. That is, similar to the federal setting, state appellate reversals that tilt favorably to defendants that lost in a jury trial likely evidence appellate and trial courts' differing perceptions regarding the accuracy of jury trial outcomes.

Although our empirical findings suggest an asymmetric distribution of appellate outcomes, we remain mindful that plausible alternative interpretations exist, partly owing to incomplete data. Indeed, selection effects likely influence the appellate setting but in unanticipated ways that can be detected in part by comparing appellate outcomes between state and federal systems. For example, although the attitudinal hypothesis might garner more consistent empirical support in explaining the distribution of reversals within the state and federal systems, selection effects provide a plausible possible explanation for differences in results between the state and federal systems.

In addition, it is logically possible that our asymmetrical findings result from a trial court tilt favoring plaintiffs rather than misperceptions at the appeals court level. Moreover, it might be that jury trials are simply more prone to reversible error than bench trials. If so, however, we are left with having to explain why plaintiff jury trial victories (rather than plaintiff and defendant jury trial victories) are significantly more prone to reversal. As well, Eisenberg and Farber raise the possibility that plaintiffs pursue lower-quality appeals, where quality is defined based on how the appellate court would decide a case ${ }^{97}$ Our findings do suggest a risk in generalizing about how a category of cases fare at trial based on how they fare on appeal. No correlation was found between plaintiffs' relative success rates across case categories at the two levels.

Finally, our data do not permit reliable testing of the possible lure of precedent setting ${ }^{98}$ and Marc Galanter's "repeat player" theory, ${ }^{99}$ both of which speak to the specter

\footnotetext{
${ }^{97}$ Eisenberg \& Farber, supra note 24.

${ }^{98}$ Priest \& Klein, supra note 11 , at 52 .
}

${ }^{99}$ Marc Galanter, Why the "Haves" Come Out Ahead: Speculations on the Limits of Legal Change, 9 L. \& Soc'y Rev. 95 (1974). 
of selection effects. Further empirical work is necessary to more rigorously test these explanations.

The existence of plausible (though, as of yet, empirically untested) alternative interpretations of our findings, however, does not detract from the practical implications that safely flow from our findings, not least of which is that the common wisdom regarding the sacrosanctness of trial jury verdicts, especially those favoring plaintiffs, may be misplaced. Findings from our study of state civil appeals should inform scholars as well as litigants and appellate judges and, we hope, help stimulate future work on this topic. 